"of many years of investigation and reflection by one of the world's leading political analysts" and as "clearly an important book." In the profession's leading journal, another reviewer called it "vintage Apter: original and suggestive, sometimes dense and opaque." He then urged graduate students in political science to read all of it, noting that "this book is not only hard reading; it both reflects hard thinking and stimulates hard thinking." This particular book well illustrates Apter's effort to liberate political phenomena from the dependent-on-other-socialeconomic-cultural-historical-or-in-anycase-not-political variables condition in which so many other social scientists, including political scientists, had placed it. Among its many merits, the book shows that "political development" is in great measure a reflection of the types of choices made by the political actors and institutions at different times and under different conditions. The point is that, whatever might be the configuration of these conditions, political leaders are free to choose among broad policy alternatives, each of which will influence the "development" that comes later.

In many of his later writings, David Apter turned his attention to political violence, of which he studied both historical and contemporary examples. In addition to many journal articles on this subject, he wrote, co-authored, or co-edited such books as gainst the State: Politics and Social Protest in Japan (Harvard University Press, 1984), an in-depth study of the longenduring protest movement against the construction of the airport at Narita; Revolutionary Discourse in Mao's Republic (with Tony Saich; Harvard University Press, 1994), a striking analysis of the meaning of Mao's mythic retreat to Ya'nan, where he created a "textual" community of critical importance in the Chinese Communist Revolution; and Political Protest and Social Change: Analyzing Politics (with Charles Andrain; Macmillan, 1995), which probes and illustrates the range of policy responses open to governmental power holders who confront organized protest, as well as the conditions that bring protest itself into existence. His edited The Legitimization of Violence (Macmillan, 1997), which deals with the origins of political violence; in it, Apter argues brilliantly against the egregiously simplistic postmodernist claim that social reality cannot be explained.
It is in this particular sector of his multifaceted intellectual output that one can find the more humorous and sardonic Apter that I knew for many years. A fine example would be his treatment of the psychobabble that so many social scientists and humanist scholars produced in their interpretations of the university student protest movements in the United States and abroad.

David Apter influenced several generations of students and colleagues not only at Yale, where we, his colleagues, enjoyed four decades of his presence. He is also remembered as a distinctive intellectual force at Northwestern, Chicago, and California (Berkeley), where he held professorships. In addition to his research in Africa, Asia, Latin America, and Europe, his lectures, visiting university appointments, and participation in professional associations and conferences took him to literally dozens of countries and cities worldwide. The breadth of his reading and knowledge, the facility with which he generated and elucidated concepts and hypotheses, and the boldness (as well as the playfulness) with which he articulated and defended his ideas about politics and society dazzled everyone, including those who might disagree with him.

During the many decades that David Apter and I shared as students, researchers, and teachers of political science, as colleagues at Yale, and, above all, as friends, he often lamented the emergence, arguably for the first time at Berkeley, of the "multiversity." He saw the latter as engaged in a reckless slicing and packaging of learning and knowledge into too many distinctive and separated organizational units. He saw and wrote about this process as one probable cause of the student revolts of the 1960s. It was in part this fragmentation that intensified his search for a political science that would span several disciplines.

It is the oldest of clichés to remark that they don't make them like that anymore, but all of us who knew David or read his many works, understand that this is exactly the case. David Apter's wife Eleanor, his children Emily and Andrew (both of them distinguished academics), his former students and colleagues, and the political and other social science professions will deeply miss his presence amongst us.

Joseph LaPalombara Yale University

\section{GARY C. BRYNER}

Professor Gary C. Bryner passed away on March 10, 2010, at age 58. Gary courageously faced the challenge of pancreatic cancer with more concern about his wife, family, and friends than for himself. Gary personified the ideal colleague. He was unfailing in his willingness to assist others with their research and was a devoted teacher. He was always first to volunteer when help was needed. Although the cancer progressed quickly, he was grateful for the time he could spend after the diagnosis with his wife, his three children and their spouses, and his three grandchildren.

Gary grew up in Salt Lake City, Utah, graduating from the University of Utah with a BA and MA in Economics. He taught high school in Salt Lake City before pursuing further graduate study in political science at Cornell University. His thinking and writing about politics was especially influenced by Professor Ted Lowi, whom Gary considered a mentor. He was a Brookings Institution Fellow in Governmental Studies in 1981-82. He completed his Ph.D. in 1982, the same year he accepted a faculty position at Brigham Young University. At BYU, Professor Bryner directed the public policy program and taught courses in public policy and American government.

Professor Bryner was a committed scholar. He remained current in his specializations and pushed himself to acquire new knowledge. A Ph.D. was not enough for him. While teaching a full load, he completed a law degree at the BYU Law School. He then used this additional advanced training in his teaching and research.

Bryner authored or edited 15 books, scores of articles and book chapters, and many academic papers. His commitment to scholarship was remarkable. His first book was Bureaucratic Discretion: Law and Policy in Federal Regulatory Agencies, which reviewer W. P. Browne described as a "skillfully written and analytical look at bureaucratic regulation" (Browne 1988, 964). His later work focused on environmental and public land policy, welfare reform, and the Constitution. His most consequential publications were his books, but his articles appeared in the Political Science Quarterly, Policy Studies Journal, Review of Policy Research, and several law reviews.

His work in the area of public lands and environmental policy is perhaps best known. In 1995 he published Blue Skies, Green Politics: The Clean Air Act of 1990 
with Congressional Quarterly Press. In his review of the book, R. M. Rakoff credits Bryner with moving beyond a legislative history to examine "the difficulties inherent in environmental policy generally" (Rakoff 1995). Two years later, he published From Promises to Performance: Achieving Global Environmental Goals (W.W. Norton, 1997). Christian Hunold, in his review of the book's examination of market-based approaches to solving environmental problems, compliments Bryner for his focus "on the ethical and political contexts in which markets actually operate" (Hunold 1999). In this same vein, he published, with Jacqueline Vaughn Switzer, Environmental Politics: Domestic and Global Dimensions (St. Martin's Press, 1998); also in 1998, he published a handbook on natural resource policy. In 2001, he published his book examining the sustainability of environmental movements. Among his edited books on the environment is his book with Neil E. Harrison, Science and Politics in the International Environment (Rowman and Littlefield, 2004). He completed and submitted his last book shortly before his death. It is forthcoming from MIT Press, with Robert Duffy as coauthor, and will be titled Integrating Energy, Climate Change, and Air Pollution Policy.

Though his primary focus was the environment, Bryner also had a keen interest in understanding U.S. welfare policy. In the area of welfare reform, Bryner published Politics and Public Morality: The Great American Welfare Reform Debate (W. W. Norton, 1998). In this book, as was typical of Professor Bryner, he involved several BYU students as research assistants, including undergraduate students.

Bryner was an active citizen of the discipline. He served as president of the Science, Technology and Environmental Research section of APSA (1993-94). He often helped organize working groups of scholars interested in working collaboratively on particular topics. Since 2001, he was a research associate at the Natural Resources Law Center, University of Colorado School of Law. He also was the director of this center from 1999 to 2001. In 2008, Professor Bryner was appointed to the APSA Ethics Committee. Professor Bryner sought professional interaction throughout his career. $\mathrm{He}$ was a Brookings Institution Guest Scholar in 1986 and 1991-92. In two consecutive years, he was a project director on two
National Academy of Public Administration projects. The first focused on the Office of Management and Budget, and the second more generally on congressional oversight.

A theme of Bryner's professional career was to draw on his professional and civic service to produce ideas for scholarship. His publications on environmental policy, for instance, were motivated by his personal passions as a committed environmentalist. In a related vein, his publications on the Constitution sprang from his taking the lead in organizing forums and other events at BYU around the bicentennial of the U.S. Constitution. In 1987, Professor Bryner published an edited book with colleague Noel Reynolds, Constitutionalism and Rights (SUNY Press). A year later, he and another BYU colleague, Dennis Thompson, published their edited volume, The Constitution and the Regulation of Society (SUNY Press, 1988). Of this volume, Don Kettl praised the quality and originality of the essays, saying, "these papers return to important basic questions" (Kettl 1989, 872). A third edited book with a BYU colleague, Don Sorensen, focused on rights and was entitled The Bill of Rights: A Bicentennial Assessment (SUNY Press, 1994). In 1995, he coauthored a book with Richard Vetterli on the founding of the American republic. These publications reveal not only Bryner's rich intellect, but also his ability to interact constructively with a diverse set of scholars.

Professor Bryner was a beloved and dedicated teacher. A teacher of ethics, Bryner's teaching was centered in humanitarian service. Whether the classroom was on campus in Washington, D.C., for BYU's Washington Seminar; in a village in Northern Mexico on an international development project; on the Navajo Indian reservation consulting with tribal leaders; or on the streets of a local low-income housing development, students benefited from Professor Bryner's concern for them and witnessed his passionate concern for other human beings. Before Bryner's death, one student commented that "what he teaches in the classroom extends to every aspect of his life. And what is more, he inspires his students to live with the same authenticity." Another said, "He is genuinely enthusiastic about civic participation, and by virtue of his example, he reinforces the notion among his students that community involvement is a privilege rather than an inconvenience."
Not surprisingly, Bryner was frequently recognized for teaching excellence by the department of political science (Pi Sigma Alpha Distinguished Faculty Award 1985, 1986, 1993, 2004), and the University awarded him the Karl G. Maeser Teaching Award in 1994. In 2006, he received the Martin B. Hickman Award in the College of Family, Home and Social Sciences for his accomplishments in teaching, scholarship, and citizenship.

Brigham Young University offers rigorous training in public policy analysis through the auspices of a Master in Public Policy degree (MPP) - a program that benefited greatly from the efforts of Gary Bryner. Bryner was the director of the graduate program from 1992-99 and led the committee that fashioned a major redesign of the program as a two-year multidisciplinary degree in the late 1990s. Bryner's scholarly expertise and wisdom in crafting the new program, as well as his skills in working with many people across the university, led to a relatively seamless transition to a new and more rigorous program.

Bryner taught a variety of graduate courses, including normative theories, environmental regulation, and policy process. Although he published critiques on the limits of economic and quantitative methods in policy analysis, he was a strong supporter of students obtaining rigorous training in all modes of policy analysis. Given his professional training and expertise in politics, ethics, economics, and policy analysis, his intellectual leadership in the MPP program had immeasurably benefits for the program and its students.

As a professor of public policy, Professor Bryner emphasized that individuals can make a difference. He modeled this attitude himself on a range of issues and in his service on the boards of the Inter-American Foundation and the Mali Rising Foundation. In 1994, he was a visiting fellow at the Natural Resources Defense Council, and he served on the board of the National Clean Air Network from 1996 to 2001.

As important as all of these accomplishments are, it is his example of kindness and gentleness that constitutes the most profound impression he left with those who knew and worked with him. He is greatly missed.

David B. Magleby Brigham Young University Sven Wilson Brigham Young University 


\section{REFEREN CES}

Browne, W. P. 1988. "Review of Bureaucratic Discretion: Law and Policy in Federal Regulatory Agencies, by Gary Bryner." Choice Magazine 25: 964.

Hunold, Christian. 1999. "Review of From Promises to Performance: Achieving Global Environmental Goals, by Gary Bryner." Journal of Policy Analysis and Management 18: 346-50.

Kettl, D. F. 1989. "Review of The Constitution and the Regulation of Society, edited by Gary Bryner and Dennis Thompson." Choice Magazine 26: 872

Rakoff, R. M. 1995. "Review of Blue Skies, Green Politics: The Clean Air Act of 1990, by Gary Bryner." Environmental History Review 19: 95-99.

\section{SAMUEL J. ELDERSVELD}

Samuel J. Eldersveld, Professor Emeritus of Political Science at the University of Michigan and former mayor of Ann Arbor, Michigan, passed away in Ann Arbor on March 5, 2010, at age 92. This closed a chapter on an extraordinary association with the University of Michigan, the discipline of political science, and the city of Ann Arbor, associations that brought remarkable change to each.

Sam was born in Kalamazoo, Michigan, in 1917 and grew up in Muskegon, Michigan, where his father was a minister in the Christian Reformed church. He was raised in a Dutch family whose ancestors immigrated to the United States in the nineteenth century. His early family experiences, the Dutch community in western Michigan, and the wider, more diverse Muskegon area played major formative roles in his development. He graduated from Muskegon high school, where his major activities in addition to his academic work were the debate team and the thespian society, contributing to traits we would all come to recognize.

Following high school, Sam attended Muskegon Junior College for two years and then graduated from Calvin College in Grand Rapids in 1938. In August 1938, he began graduate work in political science at the University of Michigan, an attachment, as Sam put it, that he never left. He received his MA in 1939 and was well into his dissertation studying urban voting patterns to understand how political party structures changed after World War I and the impact of these changes on presidential elections when this research was interrupted by service in the communications section of the U.S. Navy in the South Pacific from 1942 to 1946 . He returned to Ann Arbor in March 1946, and his Ph.D. dissertation was accepted in August 1946. He received an appointment as an instruc- tor in political science for fall 1946, beginning his long tenure in the Michigan department, a department he would transform over the next 25 years.

Although trained in traditional (for the 1930s) political science, Sam became a leader in the behavioral transformation of the discipline through his own scholarship and leadership. Collaborations with Morris Janowitz and Dwaine Marvick at the University of Michigan and attendance at a Social Science Research Council summer long conference at the University of Chicago in 1951 persuaded him that this was the necessary direction for political science and for the Michigan department. Sam, along with his students, designed and conducted one of the first field experiments since Harold Gosnell's work in the 1920 s to test the efficacy of different methods of voter contact on stimulating people to vote. The results of this study were published in the APSR in 1956. Also published in 1956 was the seminal book Political Behavior, coedited with Heinz Eulau and Morris Janowitz.

The Chicago seminar stimulated a second and more ambitious study. This study of party organizations integrated data collected from top elites, precinct activists, and the mass public. When published in 1964 as Political Parties: A Behavioral Analysis, the resulting book received the Woodrow Wilson award from the APSA as the best book published that year. This work was a long way from the traditional political science in which Sam was trained and marks a remarkable path of curiosity, creativity, self-education, and disciplined scholarship.

In 1954, Sam was awarded a Fulbright Fellowship for the Netherlands. This was a significant event that marked a major new direction in his scholarship. He had wanted to include work in the Netherlands as part of his dissertation because of its multiparty system, but this desire was blocked by the onset of World War II and the Nazi invasion of his ancestral homeland. The fellowship also marked the beginning of a scholarly journey that would take him around the globe. The work in the Netherlands is quintessential Eldersveld, combining mass data on party contact and participation with elite interviews. The ultimate elite respondent was Queen Juliana, who responded to his mail questionnaire. A second trip to the Netherlands followed in 1961, during which Sam pursued his study of Dutch parties and their contrast with U.S. parties.
Sam's next venture in comparative research, and one for which he became internationally renowned, began in 1963 , when he applied for and received a "beginner scholar" grant from the American Council for Indian Studies. This enterprise offers clear insight into Sam's intellectual curiosity and his devotion to pursuing where that curiosity led. As he admitted, he was not an Indian specialist, but he was intrigued by their multiparty system and their administrative processes. During the first stay in India, he initiated four different projects: a study of local party activists, a study of local development administration, interviews with members of the Indian parliament, and the beginning of a national election study. These were the first of many trips to and projects in India, resulting in several publications including Citizens and Politics: Mass Political Behavior in India, coauthored with Bashir Ahmed, which was the first national election study in India.

His most recent comparative adventure, on which two of us had the pleasure and privilege of working as his collaborators, began at the point that most faculty are enjoying emeritus status. In 1988, Sam began an extended collaboration with scholars from Peking University and the University of Michigan studying political and economic reform in China. This became an extended field study of mass and elite attitudes and behavior in rural towns and villages during a period of transition in Chinese politics. After numerous political and legal obstacles, the study was completed in 1993. Sam followed this up with a second set of interviews in 1996, which culminated in a book coauthored with Shen Ming-Ming, Support for Economic and Political Change in the Chinese Countryside: An Empirical Study of Cadres and Villagers in Four Counties, 1990 and 1996. The project created many memories and friendships. One that stands out is the radically altered dynamic of the project when the Chinese participants and people we interviewed discovered that Sam was a former mayor of Ann Arbor. From that point on, he was a ganbu, a leader, or, more likely, an exalted leader. Sam fit the title and played the role perfectly and always to the project's advantage. He had no difficulty moving from the study of political elites to being one, and vice-versa.

A significant feature of these comparative studies and the resultant publications is that they were all done and coauthored 